\title{
Áment Erzsébet \\ NAGY LÁSZLÓ ÉS TANÍTVÁNYA, DOMOKOSNÉ LÖLLBACH EMMA, AZ ÚJ ISKOLA ALAPÍTÓJA
}

DOI: https://doi.org/10.32558/abszolut.2021.31

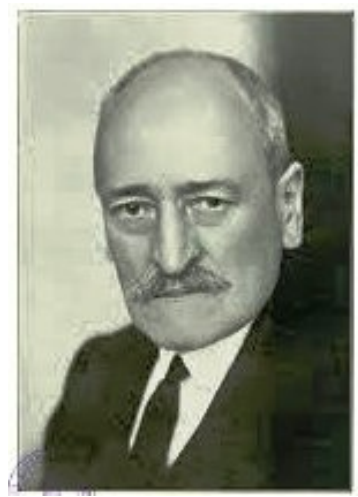

Nagy László (1857-1931)

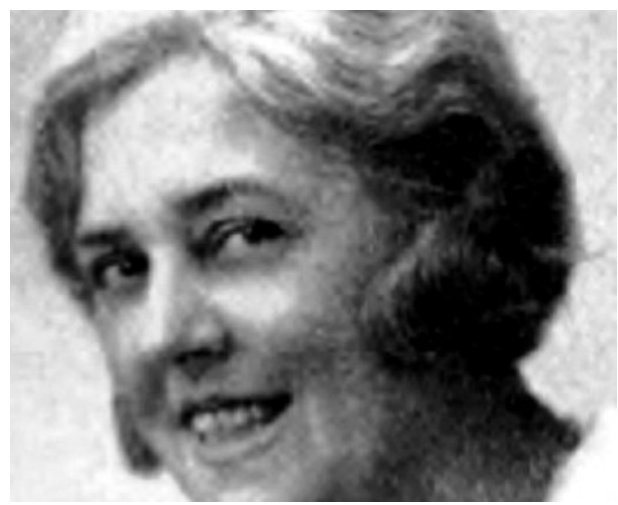

Domokosné Löllbach Emma (1885-1966)

\section{Bevezetésként a mesterről, Nagy Lászlóról}

A borsovai Nagy család ősi fészke a Tiszahát, ahol a dédapa még jómódú gazdálkodó volt. A nagyapa, Nagy András, már Kunhegyesen az iskolában a lányokat tanítja. Az apa, idősebb Nagy László kitűnő pedagógus és tanügyi író, 1875-ben bekövetkezett haláláig Pest és Jász-Kiskun megye tanfelügyelőjje. Édesanyja, Veres Mária a kisújszállási főbíró és birtokos lánya.

Nagy László Kisújszálláson 1857. június 27-én született. Elemi iskoláit Nagykőrösön végezte, ahol apja Arany János tanártársa volt, középiskolai tanulmányait a budapesti református főgimnáziumban folytatta, 1875-ben jeles érettségit tett. Egyetemi tanulmányait ugyancsak Budapesten fejezte be 1878-ban. Ezután rövid ideig a borsodi Bottlik családnál nevelősködött. 1879-80-ban a budapesti állami gyakorló fógimnáziumban gyakorló tanítóként működött; tanári diplomáját 1881-ben szerezte meg.

1881-ben kinevezték tanárnak a budai, második kerületi (Csalogány utcai) állami tanítóképzőbe. Természettudományi tárgyakat, utóbb pedagógiát oktatott. 1882-ben az Országos Nőképző Egyesület intézetében is tanított. 1886-ban családot alapított, feleségül vette Lumniczer Saroltát. 
A Magyar Tanítóképző Intézeti Tanárok Országos Egyesülete megalakulásakor, 1889-ben főtitkárává választotta, majd a következő évben a Magyar Tanítóképző című folyóirat szerkesztője lett. Előbbi tisztét 1896-ig viselte; a szerkesztéstől pedig 1907-ben vált meg, amikor megindította a Magyar Gyermektanulmányi Társaság közlönyét, az évente tíz alkalommal megjelenő folyóiratot, A Gyermeket. Mindezekért a nagy munkákért az ország tanítóképző tanárai Nagy Lászlót 1900-ban aranytollal tüntették ki. Az alig 31 éves fótitkár, amint a Családi Kapcsoskönyvében maga jegyezte föl, nagy ambícióval fogott a nem könnyű munkához, úgy érezte, hogy élete olyan eszményi célt kapott, amelyre régen vágyott.

Ez időben a Tanítóképző Intézeti Tanárok Egyesülete hazánk egyik legtevékenyebb pedagógiai társulása volt. Nagy érdemeket szerzett a tanítóképzés egységesítésében. E reformmozgalomnak megindítása és vezetése, az elért eredmények jórészt Nagy László buzgalmának köszönhetók. Nagy László szerkesztette az egyesület nagy jelentőségú emlékiratait, amelyeknek tárgyai: (I.) a tanítóképzés belső, pedagógiai reformja; (II.) a tanítóképző intézeti tanterv reformja; (III.) a tanítóképző intézeti tanárok anyagi és társadalmi helyzetének egységes rendezése és javítása.

Előadásaival „a tanítóképzés egységes törvényének alaptervezetével”, a „tanítóképző-intézeti rendtartás alapelveivel” irányt és tartalmat adott az egyesület múködésének. 1894 óta állandóan részt vett az Országos Közoktatási Tanács tanítóképző intézeti tantervi munkálataiban. 1906 óta a Tanács rendes tagja.

Nagy László nevéhez és szervezőmunkájához füződik a millennium évében, 1896-ban létrejött a II. Országos és Egyetemes Tanügyi Kongresszus. E kongresszus után I. Ferenc József a tanügyi téren „szerzett érdemei elismeréséül” tanítóképző intézeti igazgató címmel tüntette ki.

Nagy Lászlónak a közösségért végzett munka éppúgy kellett, mint a kutatómunka. Írásaival a tanítótársadalom, a kormányzat és a nagyközönség lelkiismeretét, megértését egyaránt ébresztgetni akarta. A kormányzat viszont hidegen nézte a szakszerűség szempontjait, jogászokat nevezett ki tanfelügyelőknek. Nagy László egyik törekvése a gyakorlati képzés tökéletesítése volt, a zeneoktatás, rajztanítás fontosságát hangsúlyozta, s azt, hogy a tanítókat is ennek megfelelően kell nevelni. A hazai tanítóképzés fejlesztése érdekében egyenesen közszükségletnek tartotta a külföldi példák tanulmányozást, a tanulmányutakat, még akkor is, ha az állam támogatására nem lehetett számítani. Mindent megtett annak érdekében is, hogy megszülethessen a magyarországi tanítóképzés fejlődését bemutató monográfia. 
1900-ban több tanártársával Németországban járt tanulmányúton, onnan hozta magával azt a gondolatot, hogy az akkor gyermektanulmánynak nevezett gyermeklélektannak Magyarországon egyesületet alapít. Az 1901ben tett erre irányuló javaslatát először kevés megértéssel fogadták.

1906. évi február 21-én mégis megalakulhatott a Magyar Gyermektanulmányi Társaság, amelynek ügyvivő alelnöke Nagy László lett. Élete és munkássága ettől kezdve teljesen összeforrt a megalakult Társasággal. Mind többen és többen csatlakoztak hozzájuk. A gyermekpedagógiai irodalom fellendülését eredményezte az 1907-ben alapított, A Gyermek című orgánum, amely csakhamar országosan ismertté, sőt idegen nyelvű beszámolói révén világhírűvé vált. Ugyanakkor a folyóirat a külföldi módszereket és tapasztalatokat is közvetítette olvasói számára.

Nagy László 22 évig szerkesztette A Gyermek-et; a huszonkettedik évfolyamot már nem fejezhette be.

1908-ban a VI. kerületi állami tanítóképző intézethez helyezték át, itt már csak a pedagógiai tárgyak előadója. Ebben az évben jelent meg külföldön is nagy sikert aratott könyve, A gyermek érdeklődésének lélektana.

A gyermek érdeklődésének lélektana c. művével és pedagógiai konzekvenciáinak levonásával Nagy László egyszersmind tantervelméleti koncepciójának fő tartópillérét is megépítette. Ha az oktatás az érdeklődés mesterséges (didaktikai) hatásokkal történő irányítása, akkor nyilvánvaló, hogy a tantervnek olyannak kell lennie, hogy az így értelmezett oktatást biztosítani tudja. Másik nyilvánvaló konzekvencia, a gyermeki aktivitás biztosítása, szintén a legszorosabb kapcsolatban van a gyermeki érdeklődés értelmezésével s az oktatásnak erre alapozott modern felfogásával. Összegezve elmondhatjuk, hogy Nagy László pedagógiájának egyik fó, jellemző vonása, a tanulói aktivitás kiemelése, a maga elvi megalapozását tekintve itt jelentkezik első ízben.

A könyv sikerének tudható be, hogy munkahelyén, sok évi kérelmezés után, 1909-ben engedélyt kap az első pedagógiai lélektani laboratórium megszervezésére.

1911-ben Nagy László vezetésével a magyar gyermektanulmányozók részt vettek a brüsszeli első nemzetközi gyermektanulmányi kongresszuson, csaknem húsz sikeres előadást tartottak, és nagy megbecsülést szereztek a magyar gyermektanulmányozásnak.

1916-ban az Apponyi Kollégiumban a kísérleti lélektan előadója lett. 1918-ban tanítóképző intézeti szakfelügyelővé nevezték ki. 
1921-ben jelent meg Didaktika fejlódéstani alapon c. könyve. A könyv fó gondolatait Ballér Endre az alábbi pontokba szedve foglalta össze:

1. Az oktató s nevelőmunka individualizálása.

2. A pedagógiai tevékenység lélektani alapvetésének erősítése (különösképpen az életkori sajátosságok, az érzelmek, az érdeklődés, a motiváció előtérbe helyezése).

3. A tanulói aktivitás, öntevékenység kibontakoztatása mind az oktatás, mond a nevelés terén.

4. Következetes törekvés a munkaiskola - polgári keretek között leghaladóbb - kidolgozására, megvalósítására.

5. A pályairányítás elvi és gyakorlati kérdéseinek komplex elemzése.

6. Kísérlet egy sokoldalúan nevelésközpontú s ugyanakkor a gyermek életkori sajátosságaira is alapozó tanterv kidolgozására és gyakorlati megvalósítására.

7. A megfigyelő és kísérletező módszer alkotó kombinálása.

8. S végül mindezek alapján és mindezeket egységbe foglalva: törekvése az elmélet és a gyakorlat azonosítására mind a tudományban, mind a pedagógiai tevékenységben. ${ }^{1}$

Nagy László említett törekvései korának pedagógiai gyakorlatában, tanítványa, Domokosné Löllbach Emma által 1914-ben alapított és vezetett Új Iskola munkájában eredményesnek bizonyultak. Ezt az egykori Nagytanítványok visszaemlékezései is alátámasztják sikeres életútjukkal, a nehéz körülmények közötti helytállással, erkölcsi példamutatással.

Az első magyar reformpedagógiai - vagy akár alternatív -, iskola módszere a tanítványok révén különböző külföldi iskolákba is eljutott.

Ennek bizonyítására szolgáljon egy levélrészlet. Szerzője Kelemen Mária - Mari Guha egyetemi tanár Londonban, volt iskolaalapító Indiában:

„Bluebells" lett a neve, hogy a harangvirágra emlékergtessen. Nébány éven belül mintaiskolanak neverték ki, ami ąt jelentette, hogy közeli kapcsolat alakult ki a Delbi Egyetem Pedagógia tanszékével. Rendszeresen hozzánk küldték a kutató diákokat megfigyelésre és anyaggyïjtésre. Idönként én is hozzájárultam egy-egy elöadással a tanszée programjához. A Bluebells nem véletlenül és nem is csak apróságokban tükrözte vissza az én Új Iskolás hátteremet... Igyekeztünk a tanmenetet magát a gyerekeket érdeklo" és sokszor a gyerekek által

1 Nagy László válogatott pedagógiai müvei, Szerkesztette és a bevezető tanulmányt írta: NAGY Sándor. Budapest, Tankönyvkiadó, 1972. 150. 1. 
válaszৃtott témák köré épiteni. Ez a módszer az, 50-es évek végén új volt Indiában. Nem könnyü igy tanitani. Rákényszreriteni a tanitókat, hogy odafigyeljenek a gyerekekere...Még az irástanitás is úgy kezdödött, ahogy Hermin néni tanitott engem...

1966 óta Londonban élek. Pszichológus lettem, a terïletem a gyermekfejlödés. A londoni egyetemen több mint 30 évig tanitottam ezt a tárgyat, a kognitiv pszichológia szempontjából. Sok diákom pedagógus lett. Elképzelhetó, hogy az Új Iskola hagyománya még errefelé is beszivarirgott...2

Az évkönyvek adataiból tudjuk, hogy Nagy László sokat tett az iskola elismertségéért, itthon és külföldön, szinte valamennyi gyermektanulmányozással kapcsolatos konferencián bemutatták múködését, eredményeit. Maga személyesen is igyekezett tanítóképzős hallgatóival óralátogatásokon megismertetni a különböző módszereket, a Gyermektanulmányi Társaság tanártovábbképzésein résztvevőket is gyakran vitte iskolai óralátogatásra. Magyarországon (1920-ig) valamennyi tanítóképző intézet elküldte tanárait és érdeklődő növendékeit a reformpedagógiai módszerek megismerésére az Új Iskolába.

Nagy Lászlót 1922-ben nyugdíjazták. Ezután szervezte meg a Fôvárosi Pedagógiai Szeminárium lélektani laboratóriumát.

Itt sem pihent. Ebben az időszakban született meg a több száz „pszichogram” a gyermekek testi-lelki fejlődéséről, amelyeket az Új Iskola tanulóiról, ill. tanítóképzős növendékekről készített munkatársaival.

A lélektani laboratórium vezetője volt 1931. február 25-én bekövetkezett haláláig.

Nagy László pedagógiai elméletét a gyakorlatban is megvalósító tanítványa, Löllbach Emma 1885. április 7-én született Salgótarjánban. Apja Löllbach Gusztáv, leánya születésekor bányatársulati könyvelő, későbbi hivatkozásokban bányaigazgató. Édesanyja: Gärtner Emma. Négy gyermekük született: Kálmán, Olga, Gusztáv, Emma. Kálmánnak és Emmának nem születtek gyermekei, Olga és Gusztáv leszármazottai ma is élnek.

Löllbach Emma elemi iskoláit szülőhelyén végezte. Ezután Besztercebányán a felsőbb leányiskolában tanult, majd elvégezte a budapesti II. kerületi Csalogány utcai állami tanító- és nevelőnőképzőt.

Képesitő vizsgáit kitűnő eredménnyel tette le. A vizsgáztató bizottság tagjai között elsőként szerepelt Nagy László neve, aki a képzőben tanára is volt.

A fiatal tanítónő Aradon vállalt állást, a dr. Somogyi-féle magániskolában. 1907. május 23-án házasságot kötött dr. Domokos Lászlóval.

${ }^{2}$ Hiszele ą ifjúságban! Módszerek, tanárok, diákok ą Új Iskolában, Szerkesztette: ÁMENT Erzsébet. Révai Digitális Kiadó, Budapest, 2007. 289. 1. 
Ki volt Domokos László?

Szegeden született 1882. február 6-án. Állam - és jogtudományi tanulmányokat végzett a kolozsvári egyetemen, majd visszatérve szülővárosába, Szegedre, pénzügyigazgatási tisztviselő lesz. A Délmagyarország, a Szeged és Vidékee, a Szegedi Napló rendszeresen közli cikkeit. Rokonszenves egyéniségét a Móra-levelekből ismerhetjük meg, akivel a Szegedi Napló szerkesztőségében együtt dolgozott és egy életre szóló barátságot kötöttek.

Házasságkötésük idején már két verses és egy elbeszéléskötete jelzi igazi érdeklődési területét. Így azután természetes, hogy férje mellett Emma asszony is az irodalmi összejövetelek támogatója, az írók, költők kedvence. „Irodalmi szalonjukban” megfordult Juhász Gyula, Babits Mihály, Móra Ferenc, Tömörkény István. Kedves, szelíd lényével, múveltségével, simogató, szép szavakkal válik modern „múzsává”.

Az irodalmi kömyezet, Domokos László újságírói tevékenysége, a fiatal költők ösztönzést adnak Löllbach Emmának, hogy ő is megpróbálkozzon az írással.

1908-ban jelenik meg első cikke a Szeged és Vidéke című lapban, amely hozzáértéséből adódóan pedagógiai jellegű. 1909-ben folyamatosan jelennek meg írásai elsősorban a Szeged és Vidéke címú lapban, de publikál a Szegedi Naplóban is.

Ma is aktuális témát részletez a Hány asszony boldog? című írás. A szerelem, a házasság és az anyaság az a három tényező, amely a cikkíró szerint biztosítja a nő boldogságát.

Ebben az évben Szegeden lép fel Dohnányi Ernő és Vecsey Ferenc, talán Löllbach Emma fellépésükről szóló elfogulatlan és érzéssel teli kritikája jelenti a kezdetét a Dohnányival való barátságnak, amiről később a művész nagylelkű ajándéka tanúskodik. Pénzt ad ugyanis az iskola bővítéséhez.

1910-ben keletkezett A jövő asszonya címú írás, amely a Jövendő címú, Hódmezővásárhelyen megjelent folyóiratban található. Ugyanebben az évben felvették az Erzsébet Nőiskolába, majd 1911. június 16-án keltezték polgári iskolai tanári oklevelét.

Feltételezzük, hogy Nagy László tanítványaként már előbb kapcsolatba került a tanára által kezdeményezett Gyermektanulmányi Társasággal, ismerte annak programját és jelentőségét. Tanulmányozta Nagy László könyvét, A gyermek érdeklődésének lélektanát, amelyet írója dedikálásával megkapott 1908-ban.

1909-ben A Gyermek címú lap 3. számában megjelenik könyvismertetése Lombroso Paola: A gyermek élete címú könyvéről. A Meumann szerkesztésében megjelenő Pädagogische Monographien VI. kötete ez a könyv, ennek bemutatásával 
már elkötelezte magát az akkor még fiatal tudomány, a gyermektanulmányozás, ma úgy mondanánk - gyermeklélektan - mellett.

Iskolákat látogat, gyermekrajzokat tanulmányoz, külföldi és magyar pszichológiai munkákat olvas. Hamarosan szüksége lesz erre a tudásra. Még nem múködik a Gyermektanulmányi Társaság, de már létrejött egy másik kultúra, pedagógia, múvészetpártoló közösség, amely igényt tart munkájára; felkérik előadások tartására.

Egyik előadásán Nagy László kutatásait ismerteti, a gyermeki érdeklődés fejlődési fokozatait és motívumait. Ezek a tények jól mutatják, hogy fölkészült leendő hivatására.

A sok adminisztratív jegyzőkönyvezés után végre megalakul a Gyermektanulmányi Társaság szegedi fiókköre, amelynek titkári teendőivel bízzák meg.

Mindemellett folyamatosan tájékozódik a külföldi iskolák módszereiről, a Magyar Gyermektanulmányozási Társaság fơvárosi rendezvényeinek aktív tagja.

1914-ben Domokos Lászlót Budapestre helyezik. Ez év nyarán az iskolaalapításra alkalmas házvásárlás már nem álom, hanem megvalósult tény. A Kis-Svábhegyen, a Bíró utca 16 sz. alatti magánvillát bérlik az iskola céljaira. Az átalakításban Domokosné testvérei, Kálmán és Gusztáv is segítenek, de a Domokos László életrajzkutatók szerint anyagilag a férj is hozzájárult a későbbi vásárláshoz.

Budai magániskoláját, az Új Iskolát, 1915-1949-ig, alapításától kezdve kényszerú bezárásáig, a reformpedagógiai módszerek alkalmazására, kipróbálására és továbbfejlesztésére hozta létre. Az épület ma is a XII. kerületi Bíró utca 16-18-ban található, kerítése falán hirdeti az alapító és az intézmény nevét.

A budai Új Iskola létrehozásának gondolata a Gyermektanulmányi Társaságban merült fel. A Társaság által kezdeményezett külföldi tanulmányutakról hazatérve Nagy László, Domokos Lászlóné, Grőber Vilma, Ferencz Ella - társasági tagok -, úgy ítélték meg, hogy az általuk meglátogatott intézményekben sok érdekes kezdeményezést láttak, különösen módszertani vonatkozásban. Meggyőződésük szerint a gyermektanulmányozás már nálunk is eljutott arra a szintre, hogy az összegyűjtött tapasztalatokat felhasználják. Látták azonban azt is, hogy nincs olyan hazai iskola, amelynek eddigi gyakorlatára rá lehetne építeni az oktatásnevelés új gyermeklélektani alapokon álló elméletét.

A Gyermektanulmányi Társaság elnöksége 1914-ben bízta meg Nagy Lászlót, hogy készítse az elképzeléseiknek megfelelő új iskola tantervét. 
Ovide Decroly orvos, pedagógus meghívására Nagy László már tanulmányozta annak nyolcosztályos magánintézményét Brüsszelben, melynek működéséről A Gyermek című lapban beszámolt. Ennek az intézménynek munkaiskola jellege volt, munkatermekkel, önálló tanulói munkára alkalmas berendezéssel, szerszámokkal, tanulónként a feladatok megoldásáról vezetett munkafüzetekkel.

Domokosné hivatalosan csak 1915-ben kap engedélyt az intézmény nyilvános jogú múködtetéséhez, mint a Magyar Gyermektanulmányi Társaság iskolája, a valóságban azonban mint magániskola.

Három évvel később, 1918-ban, az évvégi vizsgálaton Moussong Géza szakfelügyelő, mint a magyar királyi tanfelügyelőség kiküldöttje, elnökölt. Ott volt dr. Weszely Ödön egyetemi tanár, Répay Dániel tanítóképzőintézeti tanár, dr. Nógrádi László és a Magyar Gyermektanulmányi Társaság igazgatótanácsának számos tagja. Szülők is nagy számmal jelentek meg. Az elnök megelégedését fejezte ki a tanulók előmenetele iránt és elismerő szavakkal köszönte meg a kiváló tantestületnek a buzgó munkát. Domokos Lászlóné igazgatónak pedig, ki ennek az iskolának nemcsak megteremtője, hanem lelke, irányítója és szorgalmas munkása is, teljes elismerését fejezte ki.

A hivatalos elismerés élő bizonyítéka volt annak, hogy ez a reformiskola, dacára annak, hogy új és merész ösvényeken haladt, mégis be tudott illeszkedni a magyar népoktatás törvényes kereteibe is, ami kétségtelenül igen nagy és nehéz feladat volt és az iskola vezetőjének nagy, széles látókörét és finom pedagógiai érzékét bizonyította.

Hogyan tanít az Igazgatónő?

Az iskoláról szóló korabeli cikkek ritkán említik az igazgatónő szaktanári munkáját. Az alábbi összegzés ezt a tevékenységét is részletesen bemutatja.

„Voltak, akik a Domokos Lászlóné-féle szóképes olvasási módsz̨erek gyakorlati alkalmazása kedvéért jöttek, sürgetvén e módszer alapján megigért képes iskoláskönyvet. (Nem ábécé, mert nem a betük, hanem érdekes képek és szóképek foglalata lesz:) Nagy László szerint az olvasás tanitásában ez az egyetlen új módszer az irva - olvasó módszer és a Jacotot-féle elemző módsz̧erek óta, mert úgy a fonomimikai, mint kinesztéziciás eljárás csupán a hangok összeolvasásának könnyitésére való eljárások. A szóképekeel való olvasás azonban ij lélektani alapot nyújt az olvasástanitás számára. Mások Domokosnénak tavaly ismertetett kombinációs számolási módszerét tanulmányoztáke és alkalmazták iskolájukban kitünö eredménnyel. A II. osztály egyszeregy-tanitása lelketlen emlékezeti munka lenne a gondolkozás fejlesztése nélkë̈l, ha e minden müvelet önálló kombinálásában való gyakorlást mellöznôk. E módszer a hivatalos látogatók lelkes elismerését is kiérdemelte. 
Legtöbben a természeti megfigyelések óráit, mint amilyen tantárgy a III. és IV. elemi osztályban sehol sem szerepel, hallgatták. E tárgyat három év óta az iskola igazgatója tanitja a maga alkotta tanmenet alapján, továbbá a III. és IV. osztályok egészen új lendületü földrajzát földfejlödéstani alapon, a mesekitalálás alapján történó szabad fogalmazástanitást, a két alsó osztály beszéd-és értelemgyakorlatát.

Számosan érdeklödtek az Új Iskola által vezetett egyéniségi lapok iránt, amelyet 3 év elött Domokosné szerkesztett. Ez egyéniségi rajzok nagy feltünést keltenek az idegen iskolába átkerüló gyermekek tanárainál. Vidéki látogatók több į́ben felkérték irásban és sqóban az Új iskola igazgatóját, hogy alapitson nagyobb városokban hasonló intézményt... Ugyancsak nagy elismerésnek jele, hogy a vallás-és közoktatásügyi minisztérium az Új Iskola tudományos értékének méltánylásaként állandó államsegélyben részesiti az iskolát. Az állam segébyt már a legkö̈zelebbi tanévre ki fog utaltatni."’3

Nagy László ekkorra elkészítette az Új Iskola osztályonkénti tantervét lélekfejlődéstani alapon, nyolcosztályosra tervezett népiskolában gondolkodott, alsó négy osztályának tantervét az Új Iskola megnyitására vázlatosan elkészítette. (Néhány neveléstörténeti hivatkozás a Tanácsköztársaság időszakára datálja a 8 osztályos un. népiskolai tervet.)

A következő 4 osztályé - a tervezett felsőtagozaté -, együtt jelenik meg Didaktika fejlódéstani alapon címmel 1921-ben.

Amint címe is jelzi, nem hagyományos tantervről van szó, hanem fejlődéslélektanilag indokolt oktatási és nevelési feladatok rendszeréről, amelyeket tantárgycsoportokba sorol az életkornak megfelelően.

Nem a tantárgyi érdekekből indul ki, hanem a gyermeki pszichikum fejlődéséből, ehhez rendeli a tantárgyakat, a feldolgozás javasolt eljárásait, módszereit, olykor utal a tárgyhoz tartozó segédletekre is. Munkáját ma kerettantervnek nevezhetnénk, annyira vázlatosnak túnik. Részletesen foglalkozik azonban a tantárgyak és tantárgycsoportok funkciójával, egymással való kapcsolatával, nevelő értékével, az alkalmazható metodikával.

Az Új Iskola tantestülete erre alapozva szervezi meg éves munkáját és módszereit, természetesen a hivatalos tantervhez igazítva, ami igen megnehezíti a tervező munkát.

Nagy László, Domokos Lászlóné és az iskola tanárainak írásaiban sokszor fordul elő az aktív, cselekvő, dinamikus iskola kifejezés. Egész módszertani felfogásukban ez a legfontosabb tartópillér az érdeklődés és az életkor figyelembevételével együtt: a cselekvés a gyerekek tényleges aktivitását jelenti az ismeretfeldolgozási folyamattól az alkalmazásig bezáróan és mindez együttműködő tanulói közegben. Ez is Nagy László

3 ÁMENT Erzsébet: Emmi néni iskeolája. Magyar reformpedagógiai törekvések. OPKM. Budapest, 2005. 15. 1. 
didaktikájából következik, de a nevelőknek kell megkeresni az egyes tantárgycsoporthoz, témákhoz kapcsolható cselekedtetési módokat, amelyek nem válhatnak öncélúvá. Így keletkezett az aktív tanulói munkáltatásból az alkotó munkára nevelés, mint az Új Iskola egyik sajátossága.

Mi a munka és mi az alkotás?

Nagy László szerint munka közben a tanuló alárendeli magát más valaki által kitűzött munkacélnak. Az „alkotás” folyamán pedig a tanuló maga szab önmaga számára célt és a megoldás tartalmi és formai módját maga határozza meg. Alkotásnak, sôt „mű”-nek nevezhetjük az ilyen produkciót, habár nem jelent kultúrértéket, az egész egyén szempontjából és lélektani meghatározás szerint mégis mű, mert az egyén sajátos ereje és szándéka hozta életre és benne személyiségének minősége formát öltött.

Nagy László már az 1913-ban tartott Gyermektanulmányi Kongresszuson az alkotó munka kritériumaként az öntudatosságot, a szándékosságot állapította meg. Szerinte a külvilági dolgoknak puszta, ösztönszerû megváltoztatása még nem alkotás.

Az alkotás valamely kisebb vagy nagyobb problémának szándékos megoldása. Ebből világosan következik az alkotó munka módszerének alapelve is.

Adjunk fel problémákat a gyermeknek és engedjük, hogy azokat a maguk módján megoldják!

Az alkotó munka megvalósulását jól példázzák a budai Új Iskola eseményszámba menő munkakiállításai.

Ezek közül a legsikeresebbek:

1934. A magyar falu élete

1935. A magyar kenyér

1936. Szülőföldünk

1937. A magyar sors

1938. Szent István és kora

1939. Erdély

1942. Széchenyi István

A kiállításokat egész éven át tartó tervezés, anyaggyüjtés, formába öntés - osztályonkénti feladat-meghatározás és szervezőmunka előzi meg -a munka utolsó szakasza a legizgalmasabb: az életkoroknak megfelelő kiállítás, az ahhoz tartozó grafikonok, rajzok, festmények, tárgykészítés különböző anyagokból (agyag, papír, vásznak, termés stb.) a vállalt projekt szerint. 
A kiállítási témákhoz, évfordulókhoz osztály-, iskolai, önképzőköri pályázatok kapcsolódnak, amelyek helyezettjeit az évkönyv folyamatosan közli, olykor a nyertes múvek is olvashatók.

Nemcsak az írás, hanem a megírt darabok előadása, rendezése is mozgósítja a gimnázium tanulóit. Az sem ritka, hogy egy-egy felsős tanuló a kisebbek számára ír előadható mesét, színdarabot és azt be is tanítják. Több növendék így kap kedvet a tanításhoz, mások a karitatív munkához. De meg kell említeni a szabad fogalmazásokon, színdarab-írások alkotó tevékenységében, a közösség kritikája által csiszolódott és megerősödött tehetségeket, akik később írói, fordítói, dramaturgi foglalkozásokat választottak és érvényesültek itthon vagy külföldön.

Az Új Iskolában az alkotás maga társas egymásra hatás, telve sugalmazó erőkkel, átvett hangulatokkal, a példa, a munkaláz, az öröm hatásával. Így az alkotó munka nemcsak az ismeretszerzést és -elsajátítást, hanem a társas kapcsolatok személyiségformáló hatását is biztosította.

Nagy László és munkatársa, Domokos Lászlóné fogalomtárában tehát az alkotó munka nem a múvészeti alkotások létrehozására irányul, nem elsősorban manuális munkaformát jelent, hanem minden olyan tevékenységet, amely problémát ad és annak megoldására aktivizálja a tanulót: vagyis arra készteti, hogy addigi ismeretei felhasználásával, teremtő fantáziájával új megoldásokat keressen.

A tanításban az alkotó munkáltatás az ismeretszerzéstől az alkalmazásig tart és az egész intellektust fejleszti.

Így érthetjük meg, miért szántak nagy szerepet a tanulói kincses-füzet vezetésének - amely tanulói elnevezése egy mindenes füzetnek, amelybe kötetlenül írhatók le a gondolatok, észrevételek, megfigyelések és színes lapjai rajzolásra, gyűjtésre buzdítanak.

Nem felejthető példa a tanulmányíró számára ebből a múfajból Dienes Zoltán füzete (családi emlék Dienes Gedeonék családjában), amelyben a kert térképe szerepel, bokrok, utak külön elnevezéssel, színesen, beírva az aktuális tudnivalókat, ismereteket és gyerekes csínyeket, a napi tanulnivaló mellett.

A Magyar reformpedagógiai törekvések sorozat 5. kötetében figyelemreméltó névsort találunk a híressé vált tanítványokról.

Nagy László gyermektanulmányozási tevékenysége, a gyerekekkel és tanítóképző intézeti hallgatókkal - ezeknek egyike volt többek között Domokosné Löllbach Emma - végzett pszichológiai kísérletei alapozták meg az Új Iskolában bevezetett és az iskola megszűnéséig komolyan vett un. 
pszichogramok készitését. Ez ma a szöveges értékelés elődjének tekinthető, de nem a tantárgyi munkára, hanem elsősorban a tanuló személyiségére vonatkozik.

A pszichogramok kérdéssorát Nagy László dolgozta ki a tapasztalatok alapján. Ismeretes, hogy később hasonló módon állította össze a Pályaválasztási Intézetben a tanulókra vonatkozó személyiségi lapokat.

Domokos Lászlóné kiegészítette a kérdéssort és ő készítette fel a nevelőket ennek vezetésére. A szülők ezeket kapták meg és írták alá félévenként, később évenként. Hivatalos elnevezése a következő volt: Megfigyelések a gyermek testi és szellemi fejlődésének menetéről.

Nézzük, mire volt kíváncsi Nagy László és az Új Iskola igazgatónője, tanítója?

A gyermek neve, életkora ...

I. Testi fejlettsége:

Testmérési adatok: testmagasság, testsúly, izomerő, tüdőkapacitás.

Általános állapota: ........

II. Szellemi fejlettsége és munkabírása:

1. Figyelem. 2. Érdeklődés. 3. Felfogó- és megfigyelő-képesség. 4. Fantázia. 5. Emlékezet. 6. Gondolkodás és kombináló képesség. 7. Ítéletei önállóak-e vagy szuggerálhatók? 8. A gondolatkifejezés önálló módjai: szóban, írásban, rajzban. 9. Esztétikai érzékének fejlettsége: felfogásban, alkotásban. 10. Érzelmi élete: elmélyülő-e vagy felületes? Érzelmei könnyen megindíthatók és állandóak-e? 11. Szociális és erkölcsi magatartása: önzés vagy szociális együttélés jellemzi-e? Munkában? Játékban? Van-e erkölcsi ítélete, önkritikája? Milyen az igazságérzete? 12. Akarati élete: a. Akarata könnyen vagy nehezen megindítható-e? (Elhatározási képesség.) b. Akarata kitartó-e, vagy lobbanékony? (Koncentrálás a munkában.) c. Önálló akaratra törekvő-e?

Kezdeményező-e? Önfegyelmezésre képes-e, kötelességtudó-e?

Kövessük a Nagy László által összeállított, az aktuális tanítónéni készítette és tartalmilag Domokos Lászlóné által hitelesített egyik pszichogram részeit egy 9 éves kisfiú lapján, 1931 júniusából!

„Rendkivül ambiciózus, erös akaratú. Tetteit, szándékait mindenképpen keresżülbiszi. Nem tágit, míg eredményt nem lát. Munka köz̧ben igen koncentrált, tervszerü és ötletes.

Munkában, játékban egyaránt vezetésre termett, vele senki vitába nem száll, az. ő akaratát mindenki szó nélkëil követi. Erös kézzel, céltudatosan tudja összefogni és felhasználni a munkacsoport egyes tagjait. Ötletes, belyzetekhez gyorsan alkalmazkodni tudó, mindig újabb terveket, gondolatokat termelo", lázas, lüketetó élettempója szuggesztiv erövel hat társaira, igy azole 
is tervei keresztüllvitelében aktiv, mindig kész esžözzei. Mindamellett nem eröszakos, szigorú, de feltétlen igazságos itéleteiben, innen van nagy tekintélye társai között. Annyira a kö̈össég, a társaság és az abban kifejtett müködése az életeleme, hogy emiatt leginkább ezৃt találom legegyénibb vonásának.

Pozícioját nagyon félti és védi. Mindent félón kerül, ami tekintélyén csorbát ejthetne. Ha valamiben nehézséget talál, idegen segitséget nem szivesen vesz, igénybe, sốt társai segitségét egyenesen vissza is utasitja. „Majd én megbirkórom vele - mondja”. Önérzete nem engedi, hogy ő valaki mögött maradjon.

Érdeklödése bámulatosan sokirányú és mohó! Könyvektól, nagyobbaketól, kikeet állandóan kérdez, rengeteg ismeretet gyüjt össze, szivesen teregeti ki gazdag raktárát, de ezt a nagy mohóságot šü̈kségesnek tartanám kissé mérsékelni, mert könnyen lesz. zavarossá a sok meg nem emésztett ismeret. Altalában nem árt a könyvekröl a tapasztalati dolgok. felé irányitani.

A rajzolásban nagyon ügyes, különösen harci jeleneteket ábrázol szivesen. A sok alakot, tömegeket, amint mondja, a mozgalmas rajzokat szereti. Rajzaiban mozgás, élet van. A vezetett rajzot azonban nem szereti, mert az nem a benne éló gondolatoknak a kifejezóje.

Érzelmi életében zárkózott, érzelmeit nem mutatja, de meleg ragaszokodás és nagy emberszeretet van benne.

Csodálatos, hogy exzel a nagy akarattal, mindenképpen elöretöréssel, az elöl lenni akarással mégis nagy szerénység és az önmaga értékeinek helyes ismerése párosul és éppen ebben rejlike az ereje.

Alärta: Bothné Jeney Erssébet osztályvezetô/ tanitónö."

A tanítvány nemcsak igazgató, újító pedagógus is. Domokosné Löllbach Emma már az Új Iskola alapításának kezdő éveiben szembesül a gyermekek kezébe adható ábécéskönyvek logikai abszurditásaival. A szóképes olvasástanítást bevezető kísérleti évben, 1915-16-ban saját gyakorlatában mellőzni kényszerül a hivatalosan előírt tankönyv használatát - ezt didaktikailag is indokolja-, mivel a betúismeret kezdő szakasza után nem tudta aktívan foglalkoztatni a tanulókat.

„Most jutottunk volna az olvasókönyv használatához. Elkezdődik a passzivitás és az unalom az osztály részéról egynek kivételével, a „hol maradtunk?” vasmarkainak szorulása állandóan, büntetés, feddés a nyugtalan és ösztönösen messzebb, többhöz, belsô kielégüléshez jutni kivánó tehetségesebb, aktivabb gyermekek részére, nyögdécselés és értelmetlen zürzavarok kiböngészése az olvasó növendék számára.

Bizony én ezt nem tudtam nézni. A gyermeket belsöleg értö tanitónak mindenkor kötelessége, hogy a gyermeket ne untassa és meddó állapotban ne hagyja.

\footnotetext{
${ }^{4}$ A Magyar reformpedagógiai törekvések sorozat (szerk. ÁMENT Erzsébet) 5. kötetéből, Hiszek az ifjúságban! : Módszereke, tanárok, diákoke az Új iskolában (Budapest, 2007) kimaradt pszichogram.
} 
Az ábécés könyvek első részeinek olvastatását, vagyis az, „us, uf, ög, ug” területeit teljesen mellözve, elövettük a játék babát és játszottunk. Senki sem gondolt arra, hogy ez. olvasási óra. "'5

Milyen az Új Iskola akkori olvasókönyve?

Képeskönyv volt, minden tárgyhoz, majd komplex meseképhez cédula tartozott írott és nyomtatott betűkkel, melyeket borítékba zárva az egyes képek lapjai mellé füztek. Ezeket gyakran a felsőbb osztályos tanulók készítették, önállóan.

Domokos Lászlóné egyre elmélyültebb pedagógiai írásaival jelentkezik a szakmai fórumokon, 1937-től már mint a Magyar Pedagógiai Társaság tagja. Ebben az időszakban ír összefoglaló értekezést a magyar gyermektanulmányozás és az Új Iskola munkájáról, melyben ismét felveti a tanulók életkorától, szellemi fejlődésétől elszakadó tantárgyak és tankönyvek „mesterséges voltát”. Ugyanebből az írásból megtudjuk, hogy a növendékek „tanitási eszközö̉et készitenek, mesedélutánokat rendeznek, képeskönyveket készítenek, üjságot szerkesztenek."

Az egykori tanítványok visszaemlékezéseiből tudjuk, hogy a felsőbb osztályosok patronálták a kisebbeket, számukra képeskönyveket rajzoltak az olvasástanulás megkönnyítésére. Tehát létezett egy belső használatra készült, gyermekek által tervezett olvasókönyv.

Tudunk arról is, hogy a lelkes líceumi tanulók „saját” magyar irodalomtörténetet írtak, kézzel: Magyar irodalom, ahogy mi látjuk... címmel, 1936-37-ben. A mű két kötetesre sikerült, 420 oldalon, Halász László igazgató úrnak ajánlva. A könyv 2002-ben került elő egy lakás átalakításakor és hozzáértő kezekbe kerülve Pénzes Judit bemutatásában olvasható a Magyar Irodalomtörténeti Társaság folyóiratában, az Irodalomismeretben. (2002. 5-6. szám)

Az iskolaalapító jól ismerte a kor pedagógusainak tanmenetkészító gyakorlatát, ezért beszámol arról, hogy több iskolai értekezleten foglalkoztak a tanmenetek, osztályonkénti tanulmányi szerkezetek készítésének metodikájával, a tanterv, utasítás és tankönyv összehangolásával, példákkal illusztrálva ezek megoldhatóságát.

Domokosné a témát olyan fontosnak tartotta, hogy a Magyar Pszichológiai Társaság gyakorlati lélektani szakosztályának ankétján tartott hozzászólásában a tanterv-tankönyv-vitában a két terület szakembereinek összefogását javasolta.

Milyen volt az Új Iskola és Nagy László kapcsolata?

${ }^{5}$ Domokos Lászlóné: Az alkottató tanitás, Módszeres újitások az Új Iskolában, OPKM. 2005. 72. 1.

${ }^{6}$ DOMOKos Lászlóné: Alkotó munka az Új Iskolában, Gyermektanulmány, 127. 1. 
Domokos Lászlóné így ír róla:

„Nagy László az igazán inspirált ember belsö hajszoltságával és szenvedélyével loholt egyik problémától a másike felé, elhullatva, elfelejtve megoldott szerzęeményeit, mibelyt ujj problémába kezdett. Mindig csak afelé izzott, ami megoldatlanul iróasżtala fiókjában hevert. Velem sem beszélt majdnem semmit a kettönk közös törekvéséröl: az Uj Iskola didaktikájáról, mely az ő lélek.jejlódéstani eredményeire épiti a maga munkáját. Az egyszuer megszületett, éló, fejlödö mü célját elérte, tehát elintézett dolog volt a szemében. Ami irgató, az az új, a meg nem oldott."

Az Új Iskola a változó politikai hatalom és társadalmi közeg időszakai alatt, valamint a két nagy korszakváltás, az I. és a II. világháborút követő időben is megőrizte jellegében a legfontosabbat: a gyermekek életkorához igazított alkotó munkára és sokszínű tevékenységre épített egy „boldog iskolát", melyben szabad teret engedett a tanulói személyiség autonóm fejlődésének.

Sok szállal kapcsolódott elméletben és gyakorlatban is a külföldi, főleg európai reformpedagógia jeles képviselőihez, iskoláihoz és mindvégig igyekezett az újító törekvések áramában maradni. Nem egyszerúen felzárkózni akart, hanem lépést tartott az új módszerek kipróbálásában, adaptálásában, továbbfejlesztésében.

Domokos Lászlóné és munkatársa, Blaskovich Edit nemcsak az Új Iskola tanárai voltak, mindketten a genfi egyetem vendégtanáraként is dolgoztak, Baranyai Erzsébet pedig az amerikai reformegyetemek törekvéseit tanulmányozta, majd az iskola mellett múködő Lélektani Laboratóriumot vezette és publikálta eredményeit. Az iskola múködési elméletét megalapozó Nagy László könyveit külföldön is ismerték, méltatták.

Néhány évig az iskolában tanított a filozófus-matematikus Dienes Valéria is, a mozgásművészet, az un. „orkesztika” magyar megteremtője.

Az Európához tartozást az is jelezte, hogy a kapcsolat kétirányú volt: a külföldi kutatók folyamatos kapcsolatot tartottak az Új Iskolával, tudunk A. Ferriere, Spranger, Claparéde, Stern, Piaget látogatásáról, Bergson érdeklődéséről. A korszak híres pedagógiai egyénisége, E. Meumann több oldalt szentelt a magyar kísérleteknek, idézte Nagy László, Ranschburg Pál, Imre Sándor eredményeit.

Az egykori intézmény pedagógiai eljárásainak folytatását láthatjuk napjaink kísérletező iskoláinak módszereiben, vagy a hagyományos iskolai keretek között.

\footnotetext{
${ }^{7}$ DOMOKOS Lászlóné: Korszerü kérdések a nevelésben. OPKM, Budapest, 2005, Nagy László emlékezete, 30.1.
} 
Példa erre a belső erőket megmozgató drámapedagógia, a közös feladatokkal kooperáló csoportmunka, a cselekvő-mozgásos idegennyelvtanítás, a különböző alapfokú művészeti iskolák megjelenése. De fellelhetjük kezdetét a rajzos-képi szemléltetés-tanulásnak, a történelmi, vizuális modellezésnek is.

Az iskola karitatív tevékenységre is nevelte a tanulókat: befogadta az árvaházi tanulókat, gyúitöttek az erdélyi iskoláknak, a világháború áldozatainak, segítettek a parasztgazdaságokban, jótékonysági rendezvényeket tartottak, gyámolították a szegényeket.

Az alapító igazgató álma az volt, hogy az intézmény egykor majd gyakorlóiskolaként szolgálja a magyar tanítók képzését. Domokos Lászlóné életrajzából ismert az a tény, hogy az Új Iskolát alapításának 20. évfordulóján, 1934-ben is, felajánlotta a tanár- és tanítóképzést szolgáló, állami kísérleti iskolának.

Az erről szóló memorandumot Weszely Ödön - aki a budapesti egyetem pedagógiai tanszékének professzoraként tanári munkatervében is fontos, bemutató gyakorlószerepet szánt az intézménynek, és mint az Új Iskola Baráti Körének társelnöke - intézte volna a vallás és közoktatásügyi miniszterhez. Ez a terv a professzor hirtelen halálával meghiúsult.

Az intézményalapító azonban nem adta fel ezt a tervet, többször is próbálkozott az állami gyakorlóiskolai státus megszerzésével.

1938-39-i tanévkezdéskor az iskolát már Magyar Új Iskola Egyesület nyilvános jogú Leánygimnáziumként nevezik, alapításának 25, a leányközépiskola fennállásának 10. évfordulóján.

Egyesületi titkár a volt tanítvány, Bibó István lesz. Az iskola fenntartásával kapcsolatos ügyeket az egyesületi igazgatótanács intézi, Ugron Gábor ny. miniszter irányításával.

1948-ban az iskolát államosítják, a neve Állami Nagy László Leánygimnázium lesz.

1949. augusztus 31-én a V.k.M.1280. M.3. sz rendelet értelmében jogutód nélkül megszüntetik.

Domokosné Löllbach Emmát, az iskola alapítóját és volt igazgatóját, nyugdíjazás előtt egy évvel, a Gizella Gimnáziumba helyezték át.

A következő évben, 65 évesen nyugdijazták.

Még megérte iskolájának rehabilitációját, ugyanis jelen lehetett Buzás László kandidátusi értekezésének vitáján, amelynek címe: $A_{z}$ Új Iskola pedagógiája volt (1962).

Ugyanebben az évben kértek tőle életrajzot az akkor készülő Pedagógiai Lexikon számára. 
1966. október 6-án halt meg. Nekrológját Dienes Valéria, az iskola egykori tanára írta, mondta.

Szavait idézve: „Hatalmas szeretetmü volt ez az iskola. Nem személyek, nem tanárok, hanem a Valóság volt ott a mester. Nem tanitottak ott, csak segitettek alkotni."'

Milyen asszony volt Domokosné Löllbach Emma?

Egykor sok száz, mára egyre fogyatkozó tanítványai ma is szeretettel emlékeznek a csupa szív, derűs tanítóra, aki a „boldog iskolát” nemcsak megálmodta, hanem meg is alkotta.

De nem csak őrá, hanem szinte valamennyi, ott tanító tanárra szívesen és meghatottan emlékeztek az egykori diákok.

Voltak/vannak közöttük külföldi egyetemi tanárok, hazai kutatók, közgazdászok, akad matematikus és mûvész, írók és politikusok, szociális missziós, teológus, nyelvtanár, mérnök, táncművész.

Az egykori iskola és módszerei ma tananyagként szerepelnek egyes felsőfokú intézmények neveléstörténeti anyagában. Címszava a neten is megtalálható.

A kutató annak is örül, ha a tanítóképzésben említésre kerül a magyar reformpedagógia intézményének egykori neve, az Új Iskola.

\section{$* * *$}

A kérdés: abszolút pedagógus volt-e Nagy László és tanítványa, Domokosné Löllbach Emma?

A leírtakat összegezve - valamennyi dokumentum áttanulmányozása alapján - ez bizonyítható.

Életükben, tevékenységükben végig az „embergyerek” iránti olyan szeretet és tanítása iránti elkötelezettség munkált, amely figyelembe vette annak életkorát, érdeklődését, szabadságigényét és képességeihez mért alkotó munkára ösztönözte a világ megismerésében.

Kettőjük és számtalan közös gondolkodású ember akaratából létrejött a „boldog iskola” amelyről Löllbach Emma fiatalkorában álmodott és egész életében érte dolgozott és amelyet Nagy László elméletileg megalapozott.

Nagy Lászlót, az elméleti kutatót, aki mindig a Valóság talaján állt, az Új Iskola alapítása után még várták a következő, újabb feladatok, az újabb beteljesítendő álmok: a Gyermektanulmányi Múzeum, a Fóvárosi Pedagógiai Szeminárium lélektani laboratóriuma, a Pályaválasztási tanácsadó, a Tehetségesgyermek-kiállítások.

\footnotetext{
8 ÁMENT Erzsébet: Emmi néni iskolája, OPKM. Budapest, 2005. 75. 1.
} 
Új, friss tüzeket gyújtani a „magyar Ugaron”, új elképzeléseket megvalósítani, felrázni, aktivizálni a közvéleményt a pedagógia, a szeretetteljes gyermeknevelés és egy humánusabbnak képzelt jövő érdekében, felméréseket készítve, tanítva, cikkeket írva. Ez volt a küldetése.

Ady Endre találó kifejezésével befejezve: a tanítók tanítója egy volt az „örzơók kö̈zül, a strázsán."

Az előadás vitájában Trencsényi László feltette a kérdést, hogy a nemzetközi pedagógiai áramlatokban való jelenlét szükségszerūen hozzátartozik-e az abszolút pedagógussághoz? Ugyancsak felvetette az abszolút pedagógus kapcsolódásának kérdését a társadalmi-kulturális progresszióhoz. Véleménye szerint Domokosné kifejezetten progresszív volt, ennek kapcsán szegedi „szalonjára” hivatkozott, ahol a helybéli, de távolabbi értelmiségiek színe-java megfordult. Ugyancsak ide sorolhatók publicisztikai írásai, amelyekben nemcsak a pedagógiáról, hanem a feminizmusról, mint felszabadító életérzésrôl értekezett. Trencsényi ugyancsak meggondolandónak tartotta, hogy a diszkontinuitás, valamilyen pedagógiai nóvum létrehozása, hozzátartozik-e az abszolút pedagógushoz. Összességében egyetértett az előadóval, hogy Nagy László és Domokos Lászlóné egyaránt abszolút pedagógusoknak tekinthetők.

A vitában szó esett arról, hogy Nagy László a nevét adta a Tanácsköztársasághoz, hiszen a Közoktatásügyi Népbiztosság osztályvezetője volt, s így részt vett a közoktatáspolitika alakításában. Kiss Endre szerint azonban Nagy Lászlónak nyilván semmi különösebb köze nem volt a bolsevizmushoz. Azt tartotta az alapvető kérdésnek, hogy a gyermektanulmány (gyermeklélektan) szaktudománynak tekinthető-e vagy nem.

Hudra Árpád úgy látta, hogy Nagy László és Domokos Lászlóné egyaránt a reformpedagógia kiemelkedő és újító képviselői voltak, akik a jelenig ható érvénnyel beírták magukat a magyar pedagógia történetébe. Ugyanakkor nem igazán felelnek meg az abszolút pedagógus azon kritériumának, hogy a pedagógia területén kívül olyan kiemelkedő és nyilvános alkotótevékenységgel rendelkeztek, amely önálló és független pályát jelenthetett volna számukra.

\section{Felhasz̧nált irodalom}

Az alkotó munka az Új Iskolában Ad. Ferriere előszavával, írta DOMOKOS Lászlóné és BLASKOVICH Edith Dr. Kiadja a Magyar Gyermektanulmányozási és Nevelésügyi Társaság, Budapest. 1934

Dr. BLASKOVICH Edith: Irodalomtanítás szellemtörténeti alapon. Az alkotó munka az Új iskolában II. kötete. A tanítás problémái sorozat 28. száma. Szerkeszti: Vajthó László 
Dr. VÁRKONYI Hildebrand előszavával. Kiadja a magyar „Új Iskola” Egyesület. Királyi Magyar Egyetemi Nyomda. 1944.

ÁMENT Erzsébet (szerk.): Magyar reformpedagógiai törekvések 1-5. OPKM ÁMENT Erzsébet: A budai Új Iskola pedagógiája, OPKM. Budapest, 2005

ÁMENT Erzsébet: Emmi néni iskolája, OPKM. Budapest, 2005.

DOMOKOS Lászlóné: Az alkottató tanitás, Domokos Lászlóné összegyüjtött előadásai és cikkei 1908-1928. Szerkesztette: Áment Erzsébet. OPKM. Budapest, 2005

DOMOKOS Lászlóné: Korszerü kérdések a nevelésben, Domokos Lászlóné összegyűjtött előadásai és cikkei. 1928-1941. Szerkesztette: Áment Erzsébet. OPKM. Budapest, 2005

Hiszek az ifjúságban! : Módszerek, tanárok, diákok az Új Iskolában. Szerkesztette: ÁMENT Erzsébet. Révai Digitális kiadó, Budapest, 2007

SIMONFI Zsuzsa: Az intuició pedagógiai megközzelitése, Doktori értekezés. KGRE. Budapest, 2010. 